\title{
Synthesis of 2-Cyanopyrimidines
}

\author{
Andreas S. Kalogirou $1, * \mathbb{D}$ and Panayiotis A. Koutentis ${ }^{2} \mathbb{D}$ \\ 1 Department of Life Sciences, School of Sciences, European University Cyprus, 6 Diogenis Str., Engomi, P.O. \\ Box 22006, 1516 Nicosia, Cyprus \\ 2 Department of Chemistry, University of Cyprus, P.O. Box 20537, 1678 Nicosia, Cyprus; koutenti@ucy.ac.cy \\ * Correspondence: A.Kalogirou@euc.ac.cy; Tel.: +357-22892804
}

Received: 26 September 2019; Accepted: 21 October 2019; Published: 22 October 2019

Abstract: 4,6-Dichloro-2-(methylthio)pyrimidine (7) was converted to 4-chloro-6-methoxy-2(methylthio)pyrimidine (15) and 4,6-dimethoxy-2-(methylthio)pyrimidine (14). Chlorination of the latter with $\mathrm{N}$-chlorosuccinimide (NCS) affords 5-chloro-4,6-dimethoxy-2-(methylthio)pyrimidine (16) in 56\% yield. Both methylthiopyrimidines 15 and 14 were converted in two steps to 4-chloro-6-methoxypyrimidine-2-carbonitrile (13) and 4,6-dimethoxypyrimidine-2-carbonitrile (12), respectively, after oxidation to sulfones and displacement of the sulfinate group with KCN. 4,6-Dimethoxypyrimidine-2-carbonitrile (12) was chlorinated with NCS to give 5-chloro-4,6-dimethoxypyrimidine-2-carbonitrile (10) in 53\% yield. All new compounds were fully characterized.

Keywords: heterocycle; pyrimidine; nucleophilic displacement; chlorination

\section{Introduction}

Pyrimidines are important aromatic N-heterocycles that are found in nature, for example, as components of pyrimidine nucleotides and vitamin B1 (thiamine). Not surprisingly, the chemistry of pyrimidines has been investigated for over a century and numerous reviews have appeared [1]. Pyrimidines are also present in many drugs such as the CNS depressant phenobarbital, the anti-HIV agent zidovudine and the hyperthyroidism drug propylthiouracil (Figure 1). Additional pharmaceutical applications include uses as diuretics [2], anti-inflammatory [3], anti-malarial [4], and anti-tumor [5] agents.<smiles>CCC1(c2ccccc2)C(=O)NC(=O)NC1=O</smiles>

phenobarbital<smiles>Cc1cn(C2CC(N)C3CC2O3)c(=O)[nH]c1=O</smiles>

zidovudine<smiles>CCCc1cc(=O)[nH]c(=S)[nH]1</smiles>

propyltiouracil

Figure 1. Pyrimidine containing drugs.

Our interest in pyrimidines began with 4,5,6-trichloropyrimidine-2-carbonitrile (1), which was isolated as an unexpected minor product $(1-5 \%)$ from the reaction of tetracyanoethene (TCNE) with $\mathrm{SCl}_{2}$ during the preparation of 2-(3,5-dichloro-4H-1,2,6-thiadiazin-4-ylidene)malononitrile (2) [6] (Scheme 1). To obtain access to larger quantities of trichloropyrimidine $\mathbf{1}$, so that its chemistry could be investigated, we pursued various independent syntheses. 


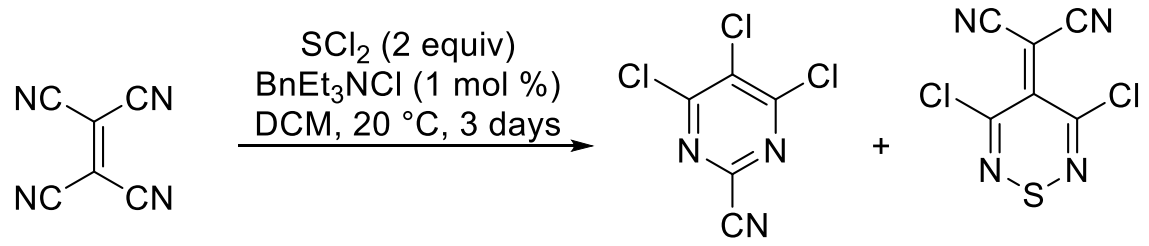

1 (5\%)<smiles>ClC1=NSN=C(Cl)C1(Cl)Cl</smiles>

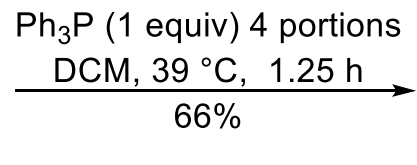<smiles>ClC1=NSC2(N=C1Cl)N=C(Cl)C(Cl)(Cl)C(Cl)=N2</smiles>

$\mathrm{BnEt}_{3} \mathrm{NCl}$ (0.5 equiv) PhMe, ca. $110^{\circ} \mathrm{C}, 24 \mathrm{~h}$ $81 \%$

3

\section{4}

Scheme 1. Preparation of trichloropyrimidine 1 from TCNE and from tetrachlorothiadiazine 3 [6,7].

To date, our most efficient synthesis of pyrimidine 1 starts from the highly reactive tetrachlorothiadiazine 3 via perchloro-9-thia-1,5,8,10-tetraazaspiro[5.5] undeca-1,4,7,10-tetraene (4) in a 53\% overall yield [7] (Scheme 1).

Below we report an alternative effort to prepare pyrimidine 1 that failed but did lead to the preparation of several new poly-substituted pyrimidines.

A retrosynthetic analysis of trichloropyrimidine 1 revealed that the cyano-group could be introduced by a nucleophilic displacement of a suitable leaving group in the $\mathrm{C} 2$ position by cyanide. Such a group could be sulfinate 5 that can be prepared by oxidation of thioether $\mathbf{6}$. The latter could be formed by $\mathrm{C} 5$ chlorination of the readily available starting pyrimidine 7 (Scheme 2).<smiles>C=C=C(C)C</smiles>

7<smiles>C=CNc1nc(Cl)c(Cl)c(Cl)n1</smiles>

6<smiles>C=C=C(Cl)c1nc(S(=O)(=O)OC)nc(Cl)c1Cl</smiles>

5<smiles>N#Cc1nc(Cl)c(Cl)c(Cl)n1</smiles>

1

Scheme 2. Retrosynthetic analysis of trichloropyrimidine $\mathbf{1 .}$

In two alternative retrosynthetic strategies, pyrimidine 1 could be formed by 4,6-dihydroxypyrimidine 8 or 4 -hydroxypyrimidine 9 (Scheme 3). These compounds could be formed by deprotection of the respective ethers $\mathbf{1 0}$ and 11. The presence of alkoxy groups in the $\mathrm{C} 5$ and $\mathrm{C} 6$ positions would enable the easier chlorination of the $\mathrm{C} 5$ in precursors $\mathbf{1 2}$ and $\mathbf{1 3}$ due to the electron-donating character of these groups. The cyano groups could be introduced in a similar manner to that described above from thioethers 14 and 15, which could be formed from chloride displacement of dichloropyrimidine 7 . 
<smiles>C=CCOc1cc(OC)nc(OC)c1</smiles><smiles>C=CCOc1cc(Cl)nc(OC)n1</smiles>

15<smiles>C=CCOc1cc(Cl)nc(C#N)n1</smiles>

13<smiles>C=C=C=C</smiles>

11<smiles>N#Cc1nc(O)c(Cl)c(Cl)n1</smiles>

9

Scheme 3. Alternative retrosynthetic analysis via methoxypyrimidines 14 and 15.

\section{Results and Discussion}

As described above, our independent synthesis began from the known 4,6-dichloro-2-(methylthio) pyrimidine (7) that was prepared in two steps and $92 \%$ overall yield from thiobarbituric acid [8]. This starting material was selected because of the availability of the starting thiobarbituric acid and the high yield of its transformation to dichloropyrimidine 7. The latter has a versatile thioether group at $\mathrm{C} 2$ that can be displaced by cyanide and chlorides at the $\mathrm{C} 4,6$ positions. Early efforts to chlorinate the $\mathrm{C} 5$ position of dichloropyrimidine 7 with either $\mathrm{NCS}$ in $\mathrm{AcOH}$, at ca. $117^{\circ} \mathrm{C}$, refluxing $\mathrm{PCl}_{5} / \mathrm{POCl}_{3}$ or neat $\mathrm{PCl}_{5}$ in a sealed tube at ca. $130{ }^{\circ} \mathrm{C}$ failed, giving only recovered starting material. Tentatively, this was attributed to the electron-deficient nature of the ring in the presence of the $\mathrm{C} 4 / 6$ electronegative chlorine atoms.

As such, we 'activated' the pyrimidine C5 position towards electrophilic chlorination by displacing one or both chlorides by the strong electron-releasing alkoxides. The substitution reaction is known $[9,10]$, but by slightly modifying the reaction procedure to involve a more concentrated reaction mixture we reduced the literature reaction time from $18 \mathrm{~h}$ to $2 \mathrm{~h}$ and obtained a high yield of methoxypyrimidine 15 (Scheme 4). Similarly, for the preparation of dimethoxy-pyrimidine 14, elevating the reaction temperature to ca. $65^{\circ} \mathrm{C}$ from $20^{\circ} \mathrm{C}$ also led to shorter reaction time $(2 \mathrm{~h}$ vs. $18 \mathrm{~h}$ ) and a high yield of 14 (Scheme 4).
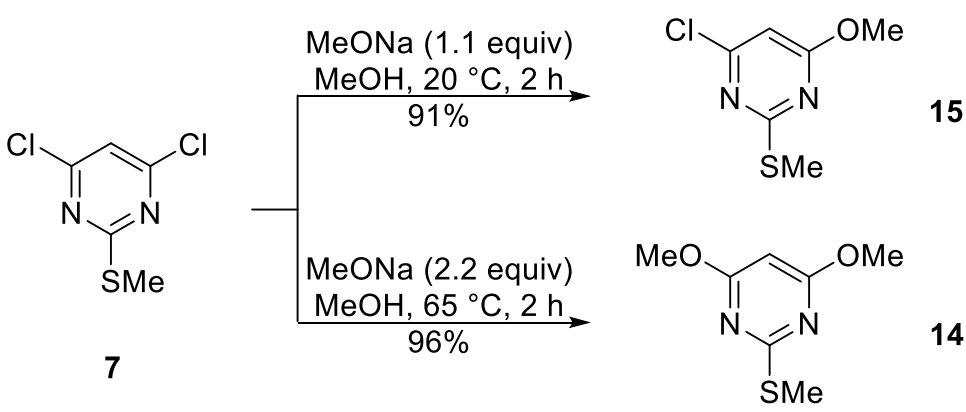

Scheme 4. Preparation of methoxypyrimidines 14 and 15.

Attempted C5 chlorination of the methoxypyrimidine 15 using either $\mathrm{NCS}_{\text {or }} \mathrm{PCl}_{5}$ as chlorinating agents failed to give a complex mixture of products, but fortunately, dimethoxy-pyrimidine 14 reacted smoothly with NCS in AcOH to give the new 5-chloropyrimidine 16 in a moderate 56\% yield (Scheme 5, see the supplementary materials for NMR spectra). 


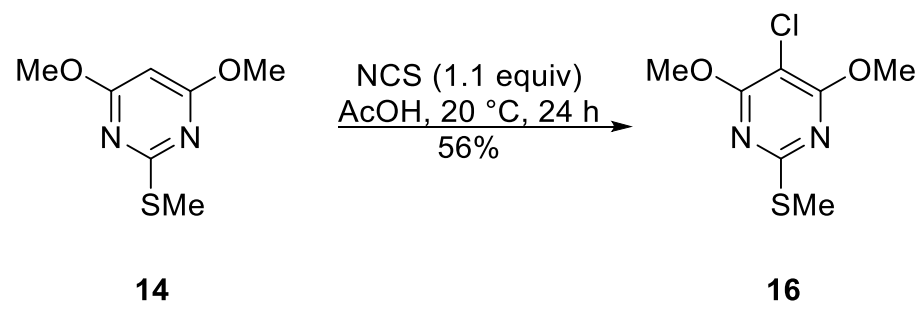

Scheme 5. Preparation of 5-chloro-4,6-dimethoxy-2-(methylthio)pyrimidine (16).

Encouraged by this result, we then proceeded to functionalize the $\mathrm{C} 2$ ring position. Oxidation of the thioether moiety in both pyrimidines $\mathbf{1 5}$ and $\mathbf{1 4}$ was performed by MCPBA (2 equiv), in DCM, at ca. $0{ }^{\circ} \mathrm{C}$, to give sulfones $\mathbf{1 7}$ and $\mathbf{1 8}$, respectively in excellent yields (Scheme 6). For comparison, the literature procedure for the preparation of methoxypyrimidine $\mathbf{1 7}$ used the oxidant oxone and obtained $78 \%$ yield of product 17 [11], whereas for dimethoxypyrimidine 18, MCPBA was used at a temperature of ca. $30{ }^{\circ} \mathrm{C}$ giving a $67 \%$ yield of product 18 [12]. Subsequent displacement of the sulfinate with $\mathrm{KCN}$ in MeCN yielded the new 2-cyanopyrimidines $\mathbf{1 3}$ and $\mathbf{1 2}$ in 27 and 83\% yields, respectively (Scheme 6, see the supplementary materials for NMR spectra).

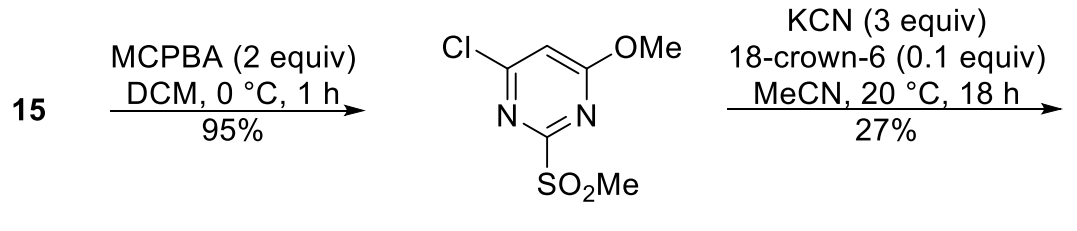

17

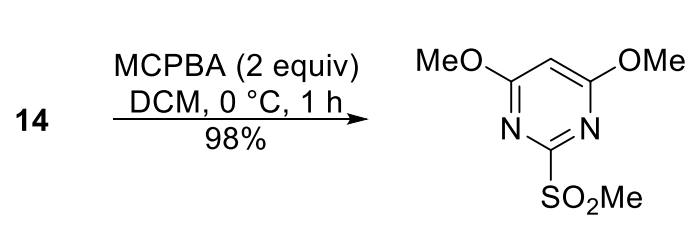

18<smiles>COc1cc(Cl)nc(C#N)n1</smiles>

13

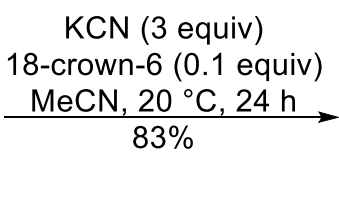<smiles>COc1cc(OC)nc(C#N)n1</smiles>

12

Scheme 6. Preparation of 4-chloro-6-methoxypyrimidine-2-carbonitrile (13) and 4,6-dimethoxypyrimidine2-carbonitrile (12).

Unfortunately, attempts to chlorinate cyanopyrimidine $\mathbf{1 3}$ failed but the chlorination of dimethoxypyrimidine $\mathbf{1 2}$ was successful and gave the new 5 -chloropyrimidine $\mathbf{1 0}$ a potential precursor to trichloropyrimidine 1 (Scheme 7, see SI for NMR spectra). Disappointingly, the subsequent step of demethylation required to reach the target compound failed. In more detail, the reaction of chloropyrimidine 10 with $\mathrm{BBr}_{3}$ (5 equiv) in DCM at ca. $20^{\circ} \mathrm{C}$ gave a complex mixture of products, while the use of TMSI in MeCN at ca. $82{ }^{\circ} \mathrm{C}$ led to degradation of the starting material to give tentatively acyclic side-products.

Although this study has not yielded the desired trichloropyrimidine 1, it has given access to four new polyfunctionalized pyrimidines that could be of use for the further investigation of the chemistry and properties of pyrimidines. 
13

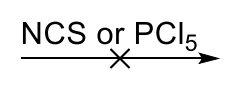

11

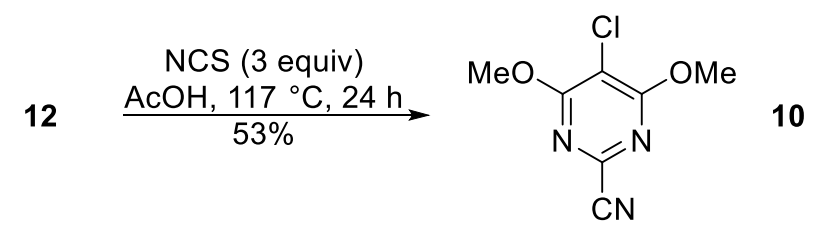

Scheme 7. Preparation of 5-chloro-4,6-dimethoxypyrimidine-2-carbonitrile (10).

\section{Materials and Methods}

The reaction mixture was monitored by TLC using commercial glass-backed thin-layer chromatography (TLC) plates (Merck Kieselgel $60 \mathrm{~F}_{254}$ ). The plates were observed under UV light at 254 and $365 \mathrm{~nm}$. Dichloromethane (DCM) and acetonitrile (MeCN) were distilled over $\mathrm{CaH}_{2}$ before use. The $1 \mathrm{M}$ and $3 \mathrm{M}$ solutions of sodium methoxide (MeONa) in methanol $(\mathrm{MeOH})$ were freshly prepared by the reaction of sodium metal with $\mathrm{MeOH}$. The melting point was determined using a PolyTherm-A, Wagner \& Munz, Kofler Hotstage Microscope apparatus (Wagner \& Munz, Munich, Germany). The solvent used for recrystallization is indicated after the melting point. The UV-vis spectrum was obtained using a Perkin-Elmer Lambda-25 UV-vis spectrophotometer (Perkin-Elmer, Waltham, MA, USA), and inflections are identified by the abbreviation "inf". The IR spectrum was recorded on a Shimadzu FTIR-NIR Prestige-21 spectrometer (Shimadzu, Kyoto, Japan) with Pike Miracle Ge ATR accessory (Pike Miracle, Madison, WI, USA) and strong, medium and weak peaks are represented by $\mathrm{s}, \mathrm{m}$ and $\mathrm{w}$, respectively. ${ }^{1} \mathrm{H}$ and ${ }^{13} \mathrm{C} \mathrm{NMR}$ spectra were recorded on a Bruker Avance 500 spectrometer [at 500 and $125 \mathrm{MHz}$, respectively, (Bruker, Billerica, MA, USA)]. Deuterated solvents were used for homonuclear lock and the signals are referenced to the deuterated solvent peaks. Attached proton test (APT) NMR studies were used for the assignment of the ${ }^{13} \mathrm{C}$ peaks as $\mathrm{CH}_{3}, \mathrm{CH}_{2}, \mathrm{CH}$, and $\mathrm{Cq}$ (quaternary). The MALDI-TOF mass spectrum (+ve mode) was recorded on a Bruker Autoflex III Smartbeam instrument (Bruker). The elemental analysis was run by the London Metropolitan University Elemental Analysis Service. 4,6-dichloro-2-(methylthio)pyrimidine (7) was prepared according to the literature procedure [8].

\section{4-Chloro-6-methoxy-2-(methylthio)pyrimidine (15)}

To a stirred mixture of 4,6-dichloro-2-(methylthio)pyrimidine (7) (585 mg, $3.00 \mathrm{mmol}$ ) in $\mathrm{MeOH}$ $(15 \mathrm{~mL})$ at ca. $20^{\circ} \mathrm{C}$ was added in one portion a solution of MeONa $1 \mathrm{M}$ in $\mathrm{MeOH}(3.30 \mathrm{~mL}, 3.30 \mathrm{mmol})$. The mixture was protected with a $\mathrm{CaCl}_{2}$ drying tube and stirred at this temperature until complete consumption of the starting material (TLC, $2 \mathrm{~h})$. $\mathrm{Et}_{2} \mathrm{O}(20 \mathrm{~mL})$ and $\mathrm{NaHCO}_{3}$ sat. (10 mL) were

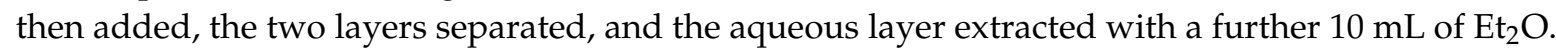
The combined organic phases were then dried over $\mathrm{Na}_{2} \mathrm{SO}_{4}$, filtered, and evaporated in vacuo to give the title compound 15 (518 mg, 91\%) as a colorless oil; $\mathrm{R}_{f} 0.31$ ( $n$-hexane/DCM, 70:30), $\delta_{\mathrm{H}}(500 \mathrm{MHz}$; $\left.\mathrm{CDCl}_{3}\right) 6.41(1 \mathrm{H}, \mathrm{s}, \mathrm{CH}), 3.96\left(3 \mathrm{H}, \mathrm{s}, \mathrm{OCH}_{3}\right), 2.55(3 \mathrm{H}, \mathrm{s}, \mathrm{SCH})$, identical to the one reported [11].

\section{4,6-Dimethoxy-2-(methylthio)pyrimidine (14)}

To a stirred mixture of 4,6-dichloro-2-(methylthio)pyrimidine (7) (780 mg, $4.00 \mathrm{mmol})$ in $\mathrm{MeOH}$ $(15 \mathrm{~mL})$ at ca. $20^{\circ} \mathrm{C}$ was added in one portion a solution of MeONa $3 \mathrm{M}$ in MeOH (2.93 mL, $\left.8.80 \mathrm{mmol}\right)$. The mixture was protected with a $\mathrm{CaCl}_{2}$ drying tube and heated to ca. $65^{\circ} \mathrm{C}$ until complete consumption of the starting material (TLC, $2 \mathrm{~h})$. DCM $(10 \mathrm{~mL})$ was then added, the mixture adsorbed onto silica, and chromatography ( $n$-hexane/DCM 70:30) gave the title compound 14 (717 $\mathrm{mg}, 96 \%$ ) as yellow plates, 
mp 53-54 ${ }^{\circ} \mathrm{C}$ (from $n$-hexane/ $-40{ }^{\circ} \mathrm{C}$, lit. 53-54 ${ }^{\circ} \mathrm{C}$ [13]); $\mathrm{R}_{f} 0.18$ (n-hexane/DCM, 70:30); $\delta_{\mathrm{H}}(500 \mathrm{MHz}$; $\left.\mathrm{CDCl}_{3}\right) 5.71(1 \mathrm{H}, \mathrm{s}, \mathrm{CH}), 3.92\left(6 \mathrm{H}, \mathrm{s}, \mathrm{OCH}_{3}\right), 2.54\left(6 \mathrm{H}, \mathrm{s}, \mathrm{SCH}_{3}\right)$, identical to the one reported [14].

5-Chloro-4,6-dimethoxy-2-(methylthio)pyrimidine (16)

To a stirred mixture of 4,6-dimethoxy-2-(methylthio)pyrimidine (14) $(93.1 \mathrm{mg}, 0.500 \mathrm{mmol})$ in $\mathrm{AcOH}(1 \mathrm{~mL})$ at ca. $20^{\circ} \mathrm{C}$ was added in one portion $\mathrm{N}$-chlorosuccinimide $(73.4 \mathrm{mg}, 0.55 \mathrm{mmol})$. The mixture was protected with a $\mathrm{CaCl}_{2}$ drying tube and stirred at this temperature until complete consumption of the starting material (TLC, $24 \mathrm{~h})$. DCM $(10 \mathrm{~mL})$ was then added, the mixture adsorbed onto silica, and chromatography ( $n$-hexane/DCM 70:30) gave the title compound 16 (61.6 $\mathrm{mg}, 56 \%)$ as colorless needles, $\mathrm{mp} 128-129^{\circ} \mathrm{C}$ (from $n$-hexane/ $-40{ }^{\circ} \mathrm{C}$ ); $\mathrm{R}_{f} 0.46$ ( $n$-hexane/DCM, 70:30); (found: $\mathrm{C}$, 37.94; $\mathrm{H}, 4.12 ; \mathrm{N}, 12.53 . \mathrm{C}_{7} \mathrm{H}_{9} \mathrm{ClN}_{2} \mathrm{O}_{2} \mathrm{~S}$ requires $\left.\mathrm{C}, 38.10 ; \mathrm{H}, 4.11 ; \mathrm{N}, 12.69 \%\right) ; \lambda_{\max }(\mathrm{DCM}) / \mathrm{nm} 258$ inf (log $\varepsilon$ 4.11), 267 (4.16); $v_{\max } / \mathrm{cm}^{-1} 2963 \mathrm{w}$ and $2930 \mathrm{w}(\mathrm{C}-\mathrm{H}), 1560 \mathrm{~m}, 1555 \mathrm{~s}, 1493 \mathrm{~m}, 1458 \mathrm{w}, 1389 \mathrm{~m}, 1358 \mathrm{~s}$, $1335 \mathrm{w}, 1319 \mathrm{~m}, 1290 \mathrm{~m}, 1269 \mathrm{~m}, 1186 \mathrm{~m}, 1182 \mathrm{~m}, 1126 \mathrm{~s}, 1070 \mathrm{~m}, 926 \mathrm{~m}, 770 \mathrm{~m} ; \delta_{\mathrm{H}}\left(500 \mathrm{MHz} ; \mathrm{CDCl}_{3}\right) 4.03$ $\left(6 \mathrm{H}, \mathrm{s}, \mathrm{OCH}_{3}\right), 2.53\left(3 \mathrm{H}, \mathrm{s}, \mathrm{SCH}_{3}\right) ; \delta_{\mathrm{C}}\left(125 \mathrm{MHz} ; \mathrm{CDCl}_{3}\right) 167.5(\mathrm{Cq}), 165.1(\mathrm{Cq}), 95.2(\mathrm{Cq}), 55.0\left(\mathrm{CH}_{3}\right)$, $14.4\left(\mathrm{CH}_{3}\right) ; \mathrm{m} / \mathrm{z}$ (MALDI-TOF) $221\left(\mathrm{M}^{+}-\mathrm{H}+2,33 \%\right), 220\left(\mathrm{M}^{+}, 75\right), 219\left(\mathrm{M}^{+}-\mathrm{H}, 100\right), 206(12)$.

4-Chloro-6-methoxy-2-(methylsulfonyl)pyrimidine (17)

To a stirred mixture of 4-chloro-6-methoxy-2-(methylthio)pyrimidine (15) (572 mg, $3.00 \mathrm{mmol}$ ) in DCM $(10 \mathrm{~mL})$ cooled in an ice-bath to ca. $0{ }^{\circ} \mathrm{C}$ was added in one portion m-chloroperbenzoic acid of $77 \%$ purity $(1.344 \mathrm{~g}, 6.000 \mathrm{mmol})$. The mixture was protected with a $\mathrm{CaCl}_{2}$ drying tube and stirred at this temperature until complete consumption of the starting material (TLC, $1 \mathrm{~h}) . \mathrm{Et}_{2} \mathrm{O}(20 \mathrm{~mL})$ and $\mathrm{Na}_{2} \mathrm{CO}_{3}$ sat. $(10 \mathrm{~mL})$ were then added, the two layers separated, and the aqueous layer extracted with a further $10 \mathrm{~mL}$ of $\mathrm{Et}_{2} \mathrm{O}$. The combined organic phases were then dried over $\mathrm{Na}_{2} \mathrm{SO}_{4}$, filtered, and evaporated in vacuo to give the title compound 17 (634 mg, 95\%) as colorless needles, $\mathrm{mp} 85-86{ }^{\circ} \mathrm{C}$ (from $n$-hexane $/ 40{ }^{\circ} \mathrm{C}$, lit. $\left.87-88^{\circ} \mathrm{C}[11]\right) ; \mathrm{R}_{f} 0.22$ ( $n$-hexane/DCM, 20:80); $\delta_{\mathrm{H}}\left(500 \mathrm{MHz} ; \mathrm{CDCl}_{3}\right) 6.92$ $(1 \mathrm{H}, \mathrm{s}, \mathrm{CH}), 4.10\left(3 \mathrm{H}, \mathrm{s}, \mathrm{OCH}_{3}\right), 3.33\left(3 \mathrm{H}, \mathrm{s}, \mathrm{SO}_{2} \mathrm{CH}_{3}\right)$; identical to the one reported [11].

\section{4,6-Dimethoxy-2-(methylsulfonyl)pyrimidine (18)}

To a stirred mixture of 4,6-dimethoxy-2-(methylthio)pyrimidine (14) (186 mg, $1.00 \mathrm{mmol}$ ) in DCM $(5 \mathrm{~mL})$ cooled in an ice-bath to ca. $0{ }^{\circ} \mathrm{C}$ was added in one portion m-chloroperbenzoic acid of $77 \%$ purity $(448 \mathrm{~g}, 3.000 \mathrm{mmol})$. The mixture was protected with a $\mathrm{CaCl}_{2}$ drying tube and stirred at this temperature until complete consumption of the starting material (TLC, $1 \mathrm{~h}) . \mathrm{Et}_{2} \mathrm{O}(20 \mathrm{~mL})$ and $\mathrm{Na}_{2} \mathrm{CO}_{3}$ sat. $(10 \mathrm{~mL})$ were then added, the two layers separated, and the aqueous layer extracted with a further $10 \mathrm{~mL}$ of $\mathrm{Et}_{2} \mathrm{O}$. The combined organic phases were then dried over $\mathrm{Na}_{2} \mathrm{SO}_{4}$, filtered and evaporated in vacuo to give the title compound $18\left(124 \mathrm{mg}, 98 \%\right.$ ) as colorless plates, $\mathrm{mp} 125-126{ }^{\circ} \mathrm{C}$ (from EtOH, lit. $\left.126-128^{\circ} \mathrm{C}[13]\right) ; \mathrm{R}_{f} 0.74(\mathrm{DCM}) ; \delta_{\mathrm{H}}\left(500 \mathrm{MHz} ; \mathrm{CDCl}_{3}\right) 6.18(1 \mathrm{H}, \mathrm{s}, \mathrm{CH}), 4.03\left(6 \mathrm{H}, \mathrm{s}, \mathrm{OCH}_{3}\right), 3.32(3 \mathrm{H}, \mathrm{s}$, $\mathrm{SO}_{2} \mathrm{CH}_{3}$ ); identical to the one reported [13].

4-Chloro-6-methoxypyrimidine-2-carbonitrile (13)

To a stirred mixture of 4-chloro-6-methoxy-2-(methylsulfonyl)pyrimidine (17) (223 mg, $1.00 \mathrm{mmol}$ ) in $\mathrm{MeCN}(5 \mathrm{~mL})$ at ca. $20^{\circ} \mathrm{C}$ was added in one portion 18 -crown- $6(26 \mathrm{mg}, 0.10 \mathrm{mmol})$ followed by $\mathrm{KCN}(195 \mathrm{mg}, 3.00 \mathrm{mmol})$. The mixture was protected with a $\mathrm{CaCl}_{2}$ drying tube and stirred at this temperature until complete consumption of the starting material (TLC, $18 \mathrm{~h}$ ). $\mathrm{Et}_{2} \mathrm{O}(20 \mathrm{~mL})$ and $\mathrm{H}_{2} \mathrm{O}$ $(10 \mathrm{~mL})$ were then added, the two layers separated, and the aqueous layer extracted with a further $10 \mathrm{~mL}$ of $\mathrm{Et}_{2} \mathrm{O}$. The combined organic phases were then dried over $\mathrm{Na}_{2} \mathrm{SO}_{4}$, filtered, and the mixture adsorbed onto silica and chromatography ( $n$-hexane/DCM 20:80) gave the title compound 13 (48 $\mathrm{mg}$, $27 \%$ ) as colorless needles, $\mathrm{mp} 69-70{ }^{\circ} \mathrm{C}$ (from $n$-hexane/ $-40{ }^{\circ} \mathrm{C}$ ); $\mathrm{R}_{f} 0.67$ ( $n$-hexane/DCM 20:80); (found: $\mathrm{C}, 42.65 ; \mathrm{H}, 2.40 ; \mathrm{N}, 24.63 . \mathrm{C}_{6} \mathrm{H}_{4} \mathrm{ClN}_{3} \mathrm{O}$ requires $\left.\mathrm{C}, 42.50 ; \mathrm{H}, 2.38 ; \mathrm{N}, 24.78 \%\right) ; \lambda_{\max }(\mathrm{DCM}) / \mathrm{nm} 241(\mathrm{log}$ ع 3.59), 262 (3.41); $v_{\max } / \mathrm{cm}^{-1} 3084 \mathrm{w}(\mathrm{C}-\mathrm{H}), 1562 \mathrm{~s}, 1533 \mathrm{~m}, 1518 \mathrm{~m}, 1470 \mathrm{~m}, 1396 \mathrm{~m}, 1360 \mathrm{~s}, 1341 \mathrm{~m}, 1244 \mathrm{w}$, $1190 \mathrm{~m}, 1130 \mathrm{~s}, 1038 \mathrm{~s}, 978 \mathrm{~s}, 945 \mathrm{~m}, 880 \mathrm{~m}, 862 \mathrm{~m}, 770 \mathrm{w} ; \delta_{\mathrm{H}}\left(500 \mathrm{MHz} ; \mathrm{CDCl}_{3}\right) 6.95(1 \mathrm{H}, \mathrm{s}, \mathrm{CH}), 4.06(3 \mathrm{H}, \mathrm{s}$, 
$\left.\mathrm{OCH}_{3}\right) ; \delta_{\mathrm{C}}\left(125 \mathrm{MHz} ; \mathrm{CDCl}_{3}\right) 170.8(\mathrm{Cq}), 161.3(\mathrm{Cq}), 143.5(\mathrm{Cq}), 114.6(\mathrm{Cq}), 111.1(\mathrm{CH}), 55.7\left(\mathrm{CH}_{3}\right) ; \mathrm{m} / \mathrm{z}$ (MALDI-TOF) $170\left(\mathrm{M}^{+}-\mathrm{H}+2,20 \%\right), 169\left(\mathrm{M}^{+}, 40\right), 168\left(\mathrm{M}^{+}-\mathrm{H}, 100\right), 132(36)$.

\section{4,6-Dimethoxypyrimidine-2-carbonitrile (12)}

To a stirred mixture of 4,6-dimethoxy-2-(methylsulfonyl)pyrimidine (18) (218 mg, $1.00 \mathrm{mmol}$ ) in $\mathrm{MeCN}(5 \mathrm{~mL})$ at ca. $20^{\circ} \mathrm{C}$ was added in one portion 18 -crown- $6(26 \mathrm{mg}, 0.10 \mathrm{mmol})$ followed by $\mathrm{KCN}(195 \mathrm{mg}, 3.00 \mathrm{mmol})$. The mixture was protected with a $\mathrm{CaCl}_{2}$ drying tube and stirred at this temperature until complete consumption of the starting material (TLC, $24 \mathrm{~h}$ ). $\mathrm{Et}_{2} \mathrm{O}(20 \mathrm{~mL})$ and $\mathrm{H}_{2} \mathrm{O}$ $(10 \mathrm{~mL})$ were then added, the two layers separated, and the aqueous layer extracted with a further 10 $\mathrm{mL}$ of $\mathrm{Et}_{2} \mathrm{O}$. The combined organic phases were then dried over $\mathrm{Na}_{2} \mathrm{SO}_{4}$, filtered, and the mixture adsorbed onto silica and chromatography (n-hexane/DCM 60:40) gave the title compound 12 (138 $\mathrm{mg}$, $83 \%$ ) as colorless needles, mp $113-114{ }^{\circ} \mathrm{C}$ (from $n$-hexane/ $-40{ }^{\circ} \mathrm{C}$ ); $\mathrm{R}_{f} 0.31$ ( $n$-hexane/DCM, 60:40); (found: $\mathrm{C}, 50.77 ; \mathrm{H}, 4.35 ; \mathrm{N}, 25.26 . \mathrm{C}_{7} \mathrm{H}_{7} \mathrm{~N}_{3} \mathrm{O}_{2}$ requires $\left.\mathrm{C}, 50.91 ; \mathrm{H}, 4.27 ; \mathrm{N}, 25.44 \%\right) ; \lambda_{\max }(\mathrm{DCM}) / \mathrm{nm}$ 259 ( $\log \varepsilon$ 3.69); $v_{\max } / \mathrm{cm}^{-1} 3094 \mathrm{w}, 3003 \mathrm{w}, 2926 \mathrm{w}$ and $2849 \mathrm{w}(\mathrm{C}-\mathrm{H}), 1591 \mathrm{~s}, 1566 \mathrm{~m}, 1530 \mathrm{~m}, 1468 \mathrm{~m}, 1387 \mathrm{~m}$, $1352 \mathrm{~m}, 1202 \mathrm{~s}, 1173 \mathrm{~m}, 1059 \mathrm{~s}, 984 \mathrm{~m}, 964 \mathrm{~m}, 864 \mathrm{~m}, 772 \mathrm{~m} ; \delta_{\mathrm{H}}\left(500 \mathrm{MHz} ; \mathrm{CDCl}_{3}\right) 6.20(1 \mathrm{H}, \mathrm{s}, \mathrm{CH}), 3.98(6 \mathrm{H}, \mathrm{s}$, $\left.\mathrm{OCH}_{3}\right) ; \delta_{\mathrm{C}}\left(125 \mathrm{MHz} ; \mathrm{CDCl}_{3}\right) 171.2(\mathrm{Cq}), 142.6(\mathrm{Cq}), 115.5(\mathrm{Cq}), 94.1(\mathrm{CH}), 54.9\left(\mathrm{CH}_{3}\right) ; \mathrm{m} / z(\mathrm{MALDI}-\mathrm{TOF})$ $166\left(\mathrm{MH}^{+}, 100 \%\right), 165\left(\mathrm{M}^{+}, 25\right), 164\left(\mathrm{M}^{+}-\mathrm{H}, 51\right), 162(55)$.

\section{5-Chloro-4,6-dimethoxypyrimidine-2-carbonitrile (10)}

To a stirred mixture of 4,6-dimethoxypyrimidine-2-carbonitrile (12) $(50.0 \mathrm{mg}, 0.303 \mathrm{mmol})$ in $\mathrm{AcOH}$ $(2 \mathrm{~mL})$ at ca. $20^{\circ} \mathrm{C}$ was added in one portion $\mathrm{N}$-chlorosuccinimide $(121 \mathrm{mg}, 0.908 \mathrm{mmol})$. The mixture was protected with a $\mathrm{CaCl}_{2}$ drying tube and stirred at ca. $117^{\circ} \mathrm{C}$ until complete consumption of the starting material (TLC, $24 \mathrm{~h})$. $\mathrm{Et}_{2} \mathrm{O}(20 \mathrm{~mL})$ and $\mathrm{H}_{2} \mathrm{O}(10 \mathrm{~mL})$ were then added, the two layers separated, and the aqueous layer extracted with a further $10 \mathrm{~mL}$ of $\mathrm{Et}_{2} \mathrm{O}$. The combined organic phases were then dried over $\mathrm{Na}_{2} \mathrm{SO}_{4}$, filtered, and the mixture adsorbed onto silica and chromatography ( $n$-hexane/DCM 60:40) gave the title compound $10\left(31.8 \mathrm{mg}, 53 \%\right.$ ) as colorless needles, $\mathrm{mp} 145-147^{\circ} \mathrm{C}$ (from $n$-hexane/ -40 ${ }^{\circ} \mathrm{C}$ ); $\mathrm{R}_{f} 0.48$ (n-hexane/DCM, 60:40); (found: $\mathrm{C}, 41.96 ; \mathrm{H}, 2.89 ; \mathrm{N}, 20.96 . \mathrm{C}_{7} \mathrm{H}_{6} \mathrm{ClN}_{3} \mathrm{O}_{2}$ requires C, 42.12; $\mathrm{H}, 3.03 ; \mathrm{N}, 21.05 \%) ; \lambda_{\max }(\mathrm{DCM}) / \mathrm{nm} 278(\log \varepsilon 3.66), 290(3.45) ; v_{\max } / \mathrm{cm}^{-1} 3003 \mathrm{w}, 2980 \mathrm{w}$ and $2918 \mathrm{w}$ (C-H), 1572s, 1566s, 1545w, 1524w, 1493w, 1462m, 1443w, 1385m, 1373s, 1362m, 1294m, 1182m, 1126s, 1088w, 1076w, 1013w, 968m, 914m, 781s, 741w, 712m; $\delta_{\mathrm{H}}\left(500 \mathrm{MHz} ; \mathrm{CDCl}_{3}\right) 4.09\left(6 \mathrm{H}, \mathrm{s}, \mathrm{OCH}_{3}\right) ; \delta_{\mathrm{C}}(125$ $\left.\mathrm{MHz} ; \mathrm{CDCl}_{3}\right) 166.0(\mathrm{Cq}), 138.5(\mathrm{Cq}), 115.1(\mathrm{Cq}), 104.4(\mathrm{Cq}), 56.1\left(\mathrm{CH}_{3}\right) ; \mathrm{m} / \mathrm{z}(\mathrm{MALDI}-\mathrm{TOF}) 202\left(\mathrm{MH}^{+}+2\right.$, 34\%), $201\left(\mathrm{M}^{+}+2,29\right), 200\left(\mathrm{M}^{+}, 38\right), 199\left(\mathrm{M}^{+}, 100\right), 192(41), 156(10)$.

Supplementary Materials: The following are available online, ${ }^{1} \mathrm{H}$ and ${ }^{13} \mathrm{C}$ NMR spectra.

Author Contributions: P.A.K. and A.S.K. conceived the experiments; A.S.K. designed and performed the experiments, analyzed the data and wrote the paper.

Funding: The research was funded by the Cyprus Research Promotion Foundation (Grants: $\Sigma$ TPATHII/0308/06, NEKYP/0308/02 ҮГEIA/0506/19 and ENIIX/0308/83).

Acknowledgments: The authors thank the following organizations and companies in Cyprus for generous donations of chemicals and glassware: the State General Laboratory, the Agricultural Research Institute, the Ministry of Agriculture, MedoChemie Ltd., Medisell Ltd. and Biotronics Ltd. Furthermore, we thank the A. G. Leventis Foundation for helping to establish the NMR facility at the University of Cyprus.

Conflicts of Interest: The authors declare no conflict of interest. The founding sponsors had no role in the design of the study; in the collection, analyses, or interpretation of data; in the writing of the manuscript, and in the decision to publish the results.

\section{References}

1. Brown, D.J. Pyrimidines and their Benzo Derivatives. In Comprehensive Heterocyclic Chemistry; Katritzky, A.R., Rees, C.W., Eds.; Pergamon Press: Oxford, UK, 1984; Volume 3, pp. 57-155.

2. Ukrainets, I.V.; Tugaibei, I.A.; Bereznykova, N.L.; Karvechenko, V.N.; Turov, A.V. 4-Hydroxy-2-quinolones 144. Alkyl-, arylalkyl-, and arylamides of 2-hydroxy-4-oxo-4H-pyrido[1,2-a]pyrimidine-3-carboxylic acid and their diuretic properties. Chem. Heterocycl. Com. 2008, 44, 565-575. [CrossRef] 
3. Amr, A.E.; Nermien, M.S.; Abdulla, M.M. Synthesis, reactions, and anti-inflammatory activity of heterocyclic systems fused to a thiophene moiety using citrazinic acid as synthon. Monatsh. Chem. 2007, 138, 699-707. [CrossRef]

4. Gorlitzer, K.; Herbig, S.; Walter, R.D. Indeno[1,2-d]pyrimidin-4-yl-amines. Pharmazie 1997, 52, 670-672.

5. Wagner, E.; Al-Kadasi, K.; Zimecki, M.; Sawka-Dobrowolska, W. Synthesis and pharmacological screening of derivatives of isoxazolo[4,5-d]pyrimidine. Eur. J. Med. Chem. 2008, 43, 2498-2504. [CrossRef] [PubMed]

6. Koutentis, P.A.; Rees, C.W. Reaction of tetracyanoethylene with $\mathrm{SCl}_{2}$; new molecular rearrangements. J. Chem. Soc. Perkin Trans. 2000, 1089-1094. [CrossRef]

7. Kalogirou, A.S.; Manoli, M.; Koutentis, P.A. Two-step conversion of 3,4,4,5-tetrachloro-4H-1,2,6-thiadiazine into 4,5,6-trichloropyrimidine-2-carbonitrile. Tetrahedron Lett. 2017, 58, 2618-2621. [CrossRef]

8. Raboisson, P.; Belfrage, A.; Classon, B.; Lindquist, K.; Nilsson, K.; Rosenquist, A.; Samuelson, B.; Wahling, H. Pyrimidine Substituted Macrocyclic HCV Inhibitors. U.S. Patent WO2008/095999A1, 14 August 2008.

9. Seganish, W.M.; Fischmann, T.O.; Sherborne, B.; Matasi, J.; Lavey, B.; McElroy, W.T.; Tulshian, D.; Tata, J.; Sondey, C.; Garlisi, C.G.; et al. Discovery and Structure Enabled Synthesis of 2,6-Diaminopyrimidin-4-one IRAK4 Inhibitors. ACS Med. Chem. Lett. 2015, 6, 942-947. [CrossRef] [PubMed]

10. Dixson, J.A.; Murugesan, N.; Barnes, K.D. Herbicidal Substituted Benzoylsulfonamides. U.S. Patent US5149357A, 22 September 1992.

11. Huang, T.-H.; Zhou, S.-S.; Wu, X.; An, L.; Yin, X.-X. Convenient synthesis of 2-(methylsulfonyl)pyrimidine derivatives. Synth. Commun. 2018, 48, 714-720. [CrossRef]

12. Zhang, J.; Zhang, L.; Zhou, Y.; Guo, Y.-L. A novel pyrimidine-based stable-isotope labeling reagent and its application to quantitative analysis using matrix-assisted laser desorption/ionization mass spectrometry. J. Mass Spectrom. 2007, 42, 1514-1521. [CrossRef] [PubMed]

13. Xu, D.; Zhu, X.; Xu, H.; Wang, Z. A facile synthesis of 4,6-dimethoxy-2-methylsulfonylpyrimidine. Asian J. Chem. 2014, 26, 313-314. [CrossRef]

14. Thomann, A.; Eberhard, J.; Allegretta, G.; Empting, M.; Hartmann, R.W. Mild and Catalyst-Free Microwave-Assisted Synthesis of 4,6-Disubstituted 2-Methylthiopyrimidines-Exploiting Tetrazole as an Efficient Leaving Group. Synlett 2015, 26, 2606-2610. [CrossRef]

(C) 2019 by the authors. Licensee MDPI, Basel, Switzerland. This article is an open access article distributed under the terms and conditions of the Creative Commons Attribution (CC BY) license (http://creativecommons.org/licenses/by/4.0/). 